\title{
Thyroglobulin Deficiency
}

National Cancer Institute

\section{Source}

National Cancer Institute. Thyroglobulin Deficiency. NCI Thesaurus. Code C121749.

Subnormal production of thyroglobulin, the glycoprotein precursor of thyroid hormones,

presumed to result from loss-of-function mutation(s) in the TG gene. 